\title{
Leadership and Communication as The Key Motivation Factors, During the Economic Crisis the Evidence of Greece
}

George Xanthakis

Department of Business Administration, Aegean University, Chios, Greece

ARTICLE INFO

Keywords:
Motivation
Leadership
Communication
Greek crisis
Civil Engineers

\begin{abstract}
The year 2010 can be considered the beginning of the economic crisis in Greece. However, hardly anybody expected that to have such substantial impact and put such pressure on the Greek economy. At that time a massive downsizing occurred and many companies even stopped their activities. In several enterprises, after organizational restructuring and downsizing, a problem with motivation of remaining employees was highlighted. The aim of the paper is to record the changes in levels of motivation. The current paper focuses on motivation as a key prerequisite for success and effectiveness of organizations and highlights the factors that related to leadership/ management and communication as the major motivation factors during the economic crisis.

A brief literature review of the motivation research, the researches that conducted during economic crisis, the leadership and the comunication are presented in the first part of it. An empirical research was conducted to explore the changes into the motivation factors that emerge in response to crisis in Greek structural design consultancies, presenting the new conditions and highlights the importance of the leadership/ management as a great motivation factor.
\end{abstract}

\section{Introduction}

The period of recession is a difficult period not only for employees but for employers, too. As the recession influences the workplace atmosphere, it is particularly difficult for each manager to increase employee motivation. However, if employees work with enthusiasm, the company may recover from the recession faster and without serious damage. Senior managers should not ignore the fact that their employees are influenced also by the way they communicate.

When the first impact of the economic crisis occurred in the companies, most of the traditional methods of motivation applied by the management before couldn't be carried out. The used tools of motivation seem to be less effective in the atmosphere of insecurity. During the recession employees lost mainly the sense of security and this situation was very stressful to them and consequently it affects the quality and employee productivity in a negative way.

According to bibliography, authors suggest that other ways and types of motivation may be applied during that period such as: developing communication within the team/ company and interaction with senior management (Hitka et al., 2006, 2010, 2011).

Motivation is the internal psychological process of initiating, energizing, directing and maintaining goal-directed behavior (Buchanan, 1997). Promoting control as a primary cultural dimension in an organizational context, the "coaching" approach encourages managementemployee partnerships Current trends show leadership and management functions converging in a type of facilitator, who, through long-term vision and shared responsibility, maintains a

* Corresponding Author E-Mail Address: xanthakisg@gmail.com 
delicate balance between flexibility and control (Mohan, 1997). The concept of change is at the forefront in today's world. Also, the understanding of leadership has changed, bringing forth the concept "Transformational Leader". Transformational leader, in order to maximize performances of workers in periods of crisis, supports them in exerting their ideas creating a synergy within the team and keeping it strong in order to preserve the motivation during crisis. He shapes the future with a vision and uses management styles such as individual information, intellectual stimulation, inspiration and affecting through idealization, in order to motivate and unite his employees around a common objective (Pınar, 2011).

\section{2. literature review}

\subsection{Motivation}

\subsubsection{Mapping motivation research}

The systematic review of existing literature highlights the different approaches to motivation in the workplace. After carefully studying the research work on motivation and related theories, we have come to the following categorization of the theoretical approaches:

\subsubsection{Motivation Theories (Content vs. Process theories)}

Content theories of motivation are based on the assumption that all people have a similar set of (unchanged) human needs and behave to meet these needs. Meeting these needs is a motivating factor. At the other hand Process theories consider that the behavior of the employees is determined and shaped by both the external environment and the individual. It is the individual who will eventually decide on how to behave and determine the intensity of the effort he will make in his work. Process theories assume that although the needs of individuals are similar, the importance and weight of them are different for the individual (dynamic view), quite subjective and leads to different behaviors.

\subsubsection{Extrinsic / intrinsic motivation factors}

A large part of the literature on work motivation has been developed around the distinction between extrinsic and intrinsic motivation. The external motivation concerns the formation and maintenance of a particular behavior, linking it to a specific (and desirable by the employee) benefits. Intrinsic motivation, on the other hand, results from the inner, psychological needs of the individual and their satisfaction through work (Ryan \& Deci, 2000). The behavior with intrinsic/ internal motivation is observed when there is no apparent reward other than the activity itself (Deci, 1975).

\subsubsection{The dynamic and multiple character of motivation}

Motivation in workplace is one of the most discussed subjects in organizational studies, and more generally in social sciences. As an object in direct relation to human behavior and internal psychological and cognitive processes, motivation is directly influenced by the specific environment in which each person operates (socio-economic environment-work environment). Despite the many related theories and approaches that have been developed, the many studies that have been conducted, no approach about work motivation has so far been able to offer a satisfactory holistic interpretation of the phenomenon (Latham, 2011), in order to develop a unified theory (ground theory). Hitka and Balazova (2015) point out in their research that motivation factors vary according to:

a) human needs

b) social conditions and lifestyle and

c) the internal and external environment of the company (Mikro-Makro environment) 


\subsection{Motivation during economic crisis (Literature Review)}

In the 2010-2015, due to the global economic crisis, studies focused on the changes in motivation factors due to this. The need for security that the employees were looking for in the workplace at the time is something that is highlighted mainly by the team of Bakanauskiene and Ubartas (2012), Zavadsky et al / 2015, Hitka and Balazova / (2015) from Slovakia and Czech Republic. In the work of Hitka et al. (2015) states that employees enjoy the appreciation from the company and that could act as motive. Zavadski et al. (2015) proposed the interaction with the Management team as an alternative way of motivation, while communication within the organization is ranked third.

Hitka et al. (2015) report internal communication as a potential motivation factor (with any extra cost) that companies should not ignore. Employees are looking for support from the organization and open communication. They are looking for a leader to inspire them, and together will go out of the crisis. Good relations with colleagues and good working conditions are ranked in high positions among the motivation factors during the crisis (Hitka and Sirotiakova / 2011).

In Jelacic (2011, Croatia), the education factor was in the third place between the motivation factors, considering it as a professional asset for the post-crisis era. In several studies during the economic crisis (Hitka and Sirotiakova / 2011, Hitka and Balazova / 2015, Zavadsky et al / 2015) an equity motivation factor and a fair assessment system are highlighted and discussed.

\subsection{Leadership}

Leadership is a "social influence process that is necessary for the attainment of societal and organizational goals (Faeth 2010). Leaders understand that they have power and that they understand the source of their power: their position; their ability to reward and to coerce; their expertise; and their personal appeal and charisma. Leadership it can be defined as the process of a leader communicating ideas, gaining acceptance of the vision and motivating followers to support and implement the ideas through others (Lussier, 2013). A leader always has the ability to influence others and may not necessarily be a manager. In bibliography (Faeth 2010) three

key Managerial/Leadership skills are recorded:

- Technical skills are ideally concerned with the ability to use methods and techniques to perform a task

- Interpersonal skills, on the other hand, focus solely on the ability to understand, communicate and work well with individuals and groups through developing effective relationships.

- Finally, decision-making skills involve the ability to conceptualize situations and select alternatives to solve problems and take advantage of opportunities

There are many types of leadership styles. In the last two decades, evidence has accumulated that transformational and autocratic leadership are the most influential types of leadership that are associated with high levels of individual and organizational performance (Kark \& Dijk 2007). The effectiveness of these leadership styles is critically contingent on, and often defined in terms of leaders' ability to motivate followers toward collective goals or a collective mission or vision. The success in leadership comes when the leadership style is matched with the characteristics of the followers. According to Chi-Ha and Walker (2008) organizational maturity and national culture play a key role in providing the foundations for leading projects using a style that maximizes trust, affective commitment and cooperation between leaders and their respective teams.

Transformational leadership seeks to change the status quo by articulating to followers, problems in the current system and a compelling vision of what a new organisation could be (Lussier 2013). Transformational leaders are often known for moving and changing things in major ways by communicating to followers a clear vision of the future by tapping into 
followers' highest ideals and motives. They effect positive change in organizational culture and learning. Transformational leadership behaviors include, among other things, four major components (Bass \& Avolio 1994):

- Inspirational motivation includes the creation and presentation of an attractive vision of the future; the use of symbols and emotional arguments; and the demonstration of optimism and enthusiasm. (Kirk and Dijk, (2007)

- Idealized influence includes such behaviours as: sacrificing for the benefit of the group; setting a personal example; and demonstrating high ethical standards.

- Individualized consideration includes providing support, encouragement, and coaching to followers.

- Finally, intellectual stimulation involves behaviours that increase an awareness of problems and challenge followers to view problems from new perspectives.

\subsection{Communication}

Leaders influence their followers' behaviour through communication, group dynamics, training, rewards and discipline. Scholarship on communication showed that communications competency of the manager has a significant role on the motivation and job satisfaction of the employees. Cushman and Craig (1976) suggested that listening and negotiating skills of the managers are the determining factors in communication competency. Pavitt (1999) noted that managers need to be collaborative in their ways of communication in a way to create a twoway channel so that employees can internalize the vision created as a team.

Communication is required for the leader as well as the organization to be efficient and effective (Zillioglu, 1996). By the help of communication, the manager can be enabled to share, assert and evaluate his/her ideas (Tutar ve Yilmaz, 2003). Rallis ve Goldring (2000) in their study found that the leadership roles have a positive effect on their collaboration skills and communication competency. Flauto (1999) studied on a typology or taxonomy of communication competence, in which he concluded that leadership is a social process involving a relationship between individuals. This relationship is enacted through communication. The same author (Flauto, (1999) also highlighted that communication competence is a prerequisite for effective leadership, as he found in his study that each of the leadership dimensions, was highly correlated with communication competency. Jurado et al. (2006) also investigated the link between communication theory and the leadership style. A recent research of Penley et al (1991) showed that the higher performing managers will exhibit, the higher levels of communication skills will be revealed. Also Wiemann and Backlund (1980) and Cupach and Spitzberg (1984) further explored the strategies for evaluating communication competency.

\subsection{Objectives}

The subject we are examining and focusing is on the wider field of HR management/leadership employee's motivation and especially in conditions of economic crisis. The research focused on a specific professional team: The Structural Design Engineers and in especially those who work with a dependent employment within a firm. The current research attempted to investigate the impact of economic crisis on the motivation factors in the working environment.

The individual objectives of the current study are set at two levels. On a first level, an overview of the motivation and motivation factors, based on a literature review of existing research work. At a second level, it's tried to explore the potential changes in the content and importance of motivational factors related to the economic circumstances and the particular characteristics of the target population. 


\section{Methodology - Grounded Theory}

The research was integrated in two phases:

Phase A

Literature review (theories and researches) based on a dynamic approach to needs

Phase B

On field research was done using a qualitative method, a small sample (12 workers in total) and semi-structured face to face interviews. The respondents worked as civil engineers in two consultancies: A (Building design projects) and B (Bridge design projects).

Table 1.

Interviews Schedule

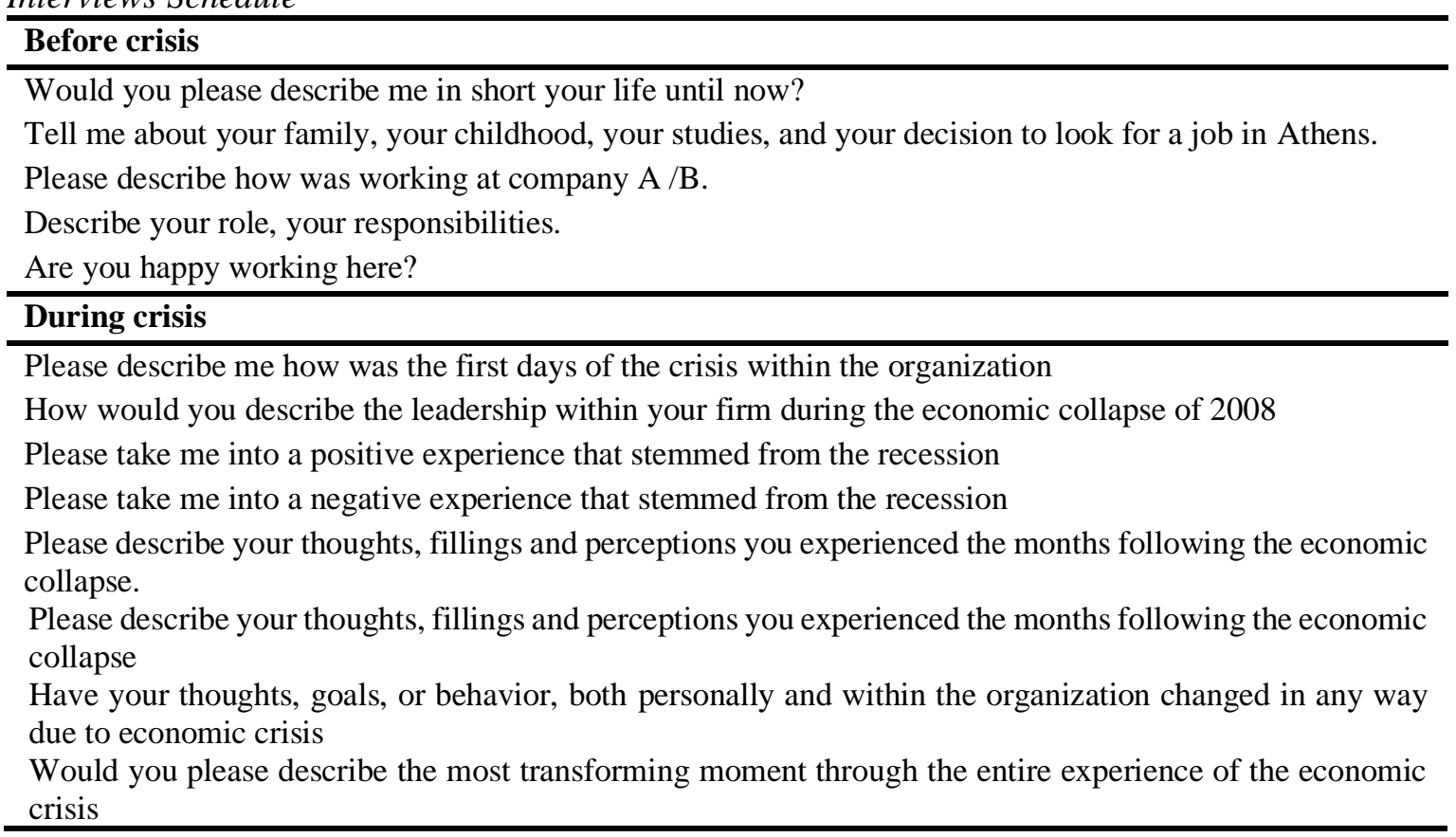

The present qualitative research is informed by a constructivist grounded theory approach (Charmaz, 2000, 2006, 2009) which is a modification of the classic grounded theory (Glasser and Strauss, 1967).

The constructivist grounded theory (Charmaz, 2000, 2006) differ from the classic (Glaser and Strauss, 1967) grounded theory approach in their beliefs about reality and the role of researcher. The constructivist grounded theory approach assumes that a) there is not a single reality but multiple (Denzin and Lincoln, 2005), and b) reality is not discovered by the researcher, but co-constructed between the researcher and the people under study (Denzin and Lincoln, 2005). The constructivist grounded theory accepts the subjectivity of researchers and their role in the co-construction of reality.

The present study follows a constructivist grounded theory approach because its ontological and epistemological assumptions are compatible and suitable with the corresponding assumptions of the present research.

\subsection{Target population - sample}

Initially, the employees, six civil engineers of company A, were selected. In this company the researcher had a long working experience. At the time of the interviews (2012-2013), we no longer belonged to the body of employees, but our privileged access to this area allowed for an in-depth understanding of respondents' answers.

Six more employees were selected by company B. Company B was chosen because, unlike A, 
its client was the Greek public sector. Initially, we had assumed that B's employees would have less insecurity given the nature of their clientele.

In this study, sampling will be used without probability and, more particularly, the convenient sampling. Convenient sampling is a sampling method that utilizes participants that are available to the researcher due to accessibility (Bryman \& Bell, 2011, p. 190). The participants were familiar to the author from before. Nevertheless, the participants were primarily chosen for the research because of their relevance for the research question and not simply because of their accessibility to the author. In this sampling, people close to the researcher are selected and represent a common feature that is attempted to study (Cohen, Manion, \& Morrison, 2008). The above type o sampling is chosen as the most appropriate because of the researcher's access to research facilities due to his work in the specific consultancy in the past.

The sample of the survey was 12 employees, 5 men and 7 women who have worked as Structural Design Engineers for 3 to 15 years, 6 worked in company A and 6 in company B. The sample, all the individuals have high level education (5 years diploma) and 3 of them holding a postgraduate degree. They are $30-45$ years old. The majority ( 9 employees) were born out of Athens and moved to Athens to find a job.

\subsection{Collect Data - Interviews}

Interviewing - and particularly the semi-structured technique - is the most widely used method. (Silverman, 2010). The use of interviews in a grounded theory approach is an appropriate and suitable method for data collection (Strauss and Corbin, 1998; Charmaz, 2006; Creswell, 2002; Silverman, 2010). I decided to include the technique of face to face semi-structure interviews in the design of the study in order to gain deep understanding of employee's ideas. The interviews were conducted in Greek and typically lasted between 50 minutes to one hour and a quarter. The interviews took place in 2013 and were completed in the second half of the year.

\subsection{Analyzing the data}

Initially the interviews were transcribed in a high level of detail and the transcripts were checked for accuracy. The data analysis includes a thematic approach (Riessman, 2003) in which the emphasis is "on the content of the data" - in "what was said". Thematic analysis, along with grounded theory requires more involvement and interpretations from the researcher's side (Guest et al, 2012).

In practice the process was executed as follows.

- Firstly, the transcripts were reviewed and important sentences or phrases, in relation to the research question were highlighted.

- Then, all the highlighted sentences were organized under each question to be able to review their similarities and differences. Following from this, the data was reviewed again to construct first order concepts.

- After this, the data was viewed again to see what second order concept could be derived from the found first order concepts and to exam if more first order concepts would be found

- After the formation of the second order themes, the aggregate dimensions/Core categories were formed based on what would simply describe each theme found.

The process is presented in Table 2 and is related to that of employee motivation during economic crisis, as it is the core of this study and of the research question.

\section{Results - Motivation factors}

The current Research work explored the motivation in a dynamic environment, taking into account the socio-economic context in which the research was conducted. In order to achieve this, a qualitative research with twelve face to face semi-structured interviews was conducted. First factor that presented to be of importance for the motivation employed in this specific 
period seems to be the manager's voice and their appreciation towards the employees. This aspect was valued very highly, even among those employees who felt like they never receive praise from their work, or whose managers simply do not show their appreciation towards their staff. This was in some cases valued even more than receiving additional compensation. The participants who had received appreciation, continued to appreciate it and acknowledge its impact on their work motivation.

Second, it's clear that the management and leadership styles that are adopted by a firm will have a determining effect on the motivation level, the morale and the job satisfaction of the employees. Nevertheless, the relationship between the management style that is used within the business and the level of motivation within the workforce is a subject of much debate. Reflecting on the discussions about motivation, it is evident that humans are very complicated and are made up of a number of traits. With motivation, these influences are both inherited and acquired from the environment and influences The characteristics of the good /manager (as a motivating factor) have been greatly modified by a "person responsible and man with knowledge and skills to solve any technical problem at work" turned into "the one who will discuss with their employees their daily problems, support them and will be their link with the Management Team".

Table 2.

Analyzing Data-Motivation Factors

\begin{tabular}{|c|c|c|c|}
\hline & First Order Concept & Second Order Concept & Core Categories \\
\hline \multirow[b]{2}{*}{ 言 } & $\begin{array}{l}\text { Increased responsibility at work } \\
\text { Signalling appreciation } \\
\text { Full working hours } \\
\text { Be proud of your work } \\
\text { Design of known buildings } \\
\text { Co-workers feedback } \\
\text { Manager comments } \\
\text { Freedom to execute }\end{array}$ & $\begin{array}{l}\text { Your effort is being noticed. } \\
\text { Comments on the quality of work. } \\
\text { Comments on the quality of work. }\end{array}$ & $\begin{array}{l}\text { Appreciation towards } \\
\text { the employees }\end{array}$ \\
\hline & $\begin{array}{l}\text { Looking for a confident and skilful leader. } \\
\text { A leader who support the employees. } \\
\text { Leader with action plan. } \\
\text { Leader who will inspire them. } \\
\text { A leader who will analyse the situation } \\
\text { and then act. } \\
\text { Supportive manager } \\
\text { A manager with understanding } \\
\text { A manager who can discuss with us } \\
\text { A manager who will be our connection } \\
\text { with the management team }\end{array}$ & $\begin{array}{l}\text { Employees looking for a leader } \\
\text { with skills, willing to lead them } \\
\text { out of the crisis. }\end{array}$ & Leadership \\
\hline \multirow[t]{2}{*}{ 芦 } & $\begin{array}{l}\text { Be informed about the future plans. } \\
\text { Know what the management team thinking. } \\
\text { Is there any action plan? } \\
\text { What is the financial situation? } \\
\text { I want to face me honestly...... }\end{array}$ & $\begin{array}{l}\text { Communication at all levels } \\
\text { Discussion with employees }\end{array}$ & Communication \\
\hline & $\begin{array}{l}\text { Co-worker support and interaction. } \\
\text { Time at work goes quickly and creatively. } \\
\text { Not anxious going to work. } \\
\text { Staying at home is boring. } \\
\text { Support and understanding to employee's needs. } \\
\text { I want to face me honestly...... }\end{array}$ & $\begin{array}{l}\text { Importance of work } \\
\text { Relation between employees }\end{array}$ & $\begin{array}{c}\text { Social needs and } \\
\text { Working Environment }\end{array}$ \\
\hline
\end{tabular}


The success of every organisation depends on its employees' drive to thrive through their efforts, commitment, engagement, practice and persistence. Thus, motivation is an important topic because leadership competencies include the ability to motivate employees as one of the crucial duties of the role. Leadership begins with the initial effort made to recruit a new employee; proceeds through the entire induction process; and continues every day until the employee departs the organisation. This process is cultivated by a manager/leader, motivating new employees and it highlights, once again, the importance of leadership to an organisation. The quality of a manager's relationship with an employee is the most powerful element of employee motivation. It creates a professional, positive and respectful attitude and employees are more likely to adopt a similar approach with their peers and enjoy work.

Third conclusion that can be drawn is that feedback and the communication is tremendously important for employees. They tend to value the feedback received from their colleagues and the managers. Feedback is also very closely related to the amount of work motivation that employee feel. Feedback indicates how they are doing their work and without indications of this work motivation is harder to achieve. The communication with the management team , the information about their plan and their schedule to deal with the crisis is a fundamental for employees and their wiring in this. The need for communication / information from management on the current situation, future actions and plans to exit the crisis has emerged as a key driver of motivation.

At last the social aspects at work can't be ignored as motivation factors during the economic crisis. The socialization can be with the management team and/ or with colleagues. The motivation factor of stability and security has been replaced by the satisfaction of the need to belong to a social / work place.

\section{Discussion}

\subsection{Limitations of current research and recommendations for future research}

The current research has several limitations. The first limitation regards the role of the researcher during the field work and the potential impact in the research process. A second limitation is that research took place in the setting of a time and place employees' group that may differ in terms of purpose and structure from other workgroups. The findings are not easily transferable to other settings although they could offer useful insights in studying employee motivation, in general. This last limitation produces a recommendation for future research to include additional employees' groups in the single study. The comparison between different workgroups could enable a more fruitful exploration of the role of motivation. A third limitation regards issues like power relations that are not addressed in the study. Future research should explicitly take them into consideration since power relations could further enhance our understanding of motivation in workplace (Zanoni et al., 2010).

\subsection{Contribution of the study}

The current study attempts to make a contribution in the field of motivation in workplace. Taking into consideration the suggestions of several scholars (Hitka and Sirotiakova / 2011, Hitka and Balazova / 2015, Zavadsky et al / 2015), who point out the need for additional research on employee motivation in the workplace. The research findings position the present study along other studies in the literature that emphasize the multiple character of motivation.

\section{References}

Abbas, W. \& Asgar, I. 2010. The role of leadership in organizational change: Relating the successful organizational change to visionary and innovative leadership. Master's Thesis. University of Gavle. 
Bass, B.M., B.J. Avolio, (1994). Improving organizational effectiveness through transformational leadership. Thousand Oaks, CA: Sage.

Buchanan, D., Huczynski, A., 1997. Organizational behaviour, Prentice Hall, Third Edition, Prentice Hall Europe.

Charmaz, K. (2000). Grounded theory: Objectivist and Constructivist Methods. In N. K. Denzin and Y. S. Lincoln (Eds.), Handbook of Qualitative Research. 2nd ed., (pp. 509535). Thousand Oaks, CA: Sage.

Charmaz, K. (2006). Constructing grounded theory: a practical guide through qualitative analysis, London: Sage.

Charmaz, K. (2008). Grounded Theory. In J. A. Smith (Ed.), Qualitative psychology: a practical guide to research methods (pp. 81-110). Thousand Oaks: Sage

Chatzopoulou M., Vlacvei A. Monovasilis Th., 2015. Employee's Motivation and Satisfaction in light of Economic Crisis: Evidence of Grevana Prefecture-Greece. Procedia Economics and Finance 24 (2015), pp 136-145.

Creswell, J. W. (1998). Qualitative inquiry and research design: Choosing among five traditions. Thousand Oaks: Sage.

Cupach, W. R., \& Spitzberg, B. H. 1981.Relational competence: Measurement and validation. Paper presented at the annual meeting of the Western Speech Communication Association, San Jose, CA.

Cushman, D.P., and Craig, R. T. 1976. Communication systems: Interpersonal implications. In G.R. Miller (Ed.), Exploration in interpersonal communication. Beverly Hills: Sage Publications.

Denzin, N. K., \& Lincoln, Y. S. (Eds.). (2005). The Sage handbook of qualitative research (3 ${ }^{\text {rd }}$ ed.). London: Sage.

Faeth, M.A. 2010. Power, authority and influence: A comparative study of the behavioural influence tactics used by lay and ordained in the Episcopal Church. Doctoral Philosophy. Virginia

Flauto, F.J. 1999. Walking the talk: The relationship between leadership and communication competence. Journal of Leadership \& Organizational Studies, 6(2), 86-97.

Glaser, B. \& Strauss, A. (1967). The Discovery of Grounded Theory: Strategies for Qualitative Research, Chicago, Aldine Publishing Company.

Grammatikopoulos, I., Koupidis, S., Moralis, D., Sadrazamis, A., Athinaiou, D. and Giouzepas, I., 2013. Job motivation factors and performance incentives as efficient management tools: A study among mental health professionals, Archives of Hellenic Medicine/Arheia Ellenikes Iatrikes

Guba, E. G., \& Lincoln, Y. S. (1994). Competing paradigms in qualitative research. In.

Guest, G., MacQueen K.M., Namey, E.E, (2012). Applied Thematic Analysis. California: Sage Publications. [e-book].

Hitka, M. \& Balazova, Z. (2014). Comparison of Motivational level of Service Sector Employees in the regions of Austria and Slovakia. Procedia Economics and Finance 23(2014), 348-355.

Hitka, M. \& Sirotiakova, M. (2011). The impact of the economic crisis on change in motivation of furniture company employees-case study. Wood technology Institute 
Hitka, M., Zavadska, Z., Jelasic, D. \& Balazova Z. (2015). Qualitative Indicators of Employee Satisfaction and their Development in a particular period of time. DRVNA INDUSTRIJA 66(3), 235-239.

Jelasic D., 2011, Motivating of Wood company processing and furniture manufacturing companies employees in time of economic crisis. Human Resources management and Economics and ICT Volume V. 1/2011. John Wiley and Sons.

Kark, R. \& Dijl, D.V. 2007. Motivation to lead, Motivation to follow: The role of the selfregulatory focus in leadership processes. Academy of Management Review, 32(2): 500528.

Latham, G.P. \& Pinder, C. C., (2005). Work motivation theory and research at the dawn of the twenty-first century. Annual Review of Psychology, 56 (1), 485-516.

Lussier, A. 2010. Effective Leadership. $5^{\text {th }}$ ed. Cengage learning. South Western.

Mohan, M.L., 1993 Organizational communication and cultural vision, state University of New York Press, New York

Pavitt, C. (1999). Theorizing about the group communication-leadership relationship. Input output and functional models. In: L.R. Frey (ed.) The handbook of group communication theory and research. London, Spon: 313-334.

Penley, L. E., Alexander, E. R., Jernigan, I. E., \& Henwood, C. I. (1991). Communication abilities of managers: The relationship to performance. Journal of Management, 1, 57-76.

Pinar A., 2011 Applicable vision, mission and the effects of strategic management on crisis resolve. Procedia Social and Behavioral Sciences 24, 61-71, 2011

Pinder, C. C. (2014). Work Motivation in Organizational Behavior. $2^{\text {nd }}$ Edition. New York: Psychology Press. Psychological Review 84, 191-215.

Riessman, C. K. (2003). Narrative Analysis. Qualitative. Research Methods Series (Vol. 30).

Ryan, R.M. \& Deci, E.L. 2000. Intrinsic and extrinsic motivation: Classic definitions and new directions. Contemporary Educational Psychology, 25: 54-97.

Shamir, B., Zakay, E., Breinin E. B., \& Popper, M. 1998. Correlates of charismatic leader behavior in military units: Subordinates' attitudes, unit characteristics, and superiors' appraisals of leader performance. Academy of Management Journal, 41: 387-409.

Silverman D., 2010. Doing Qualitative Research. London 2010. Sage publications $3^{\text {rd }}$ Edition.

Wiemann, J. M., \& Backlund, P. (1980). Current theory and research in communicative competence. Review of Educational Research, 50(1), 185199.

Zavadsky J., Hitka M. Potkany M., 2015. Changes of employee motivation of Slovak enterprises due to Global Economic Crisis. Business administration and Management XVIII, 2015, p p . 57-66. 